\title{
BILATERAL FACIAL PALSY IN A YOUNG PATIENT AFTER MENINGOCOCCAL MENINGITIS, ASSOCIATED TO HERPETIC INFECTION
}

\author{
Edna Quintas' ${ }^{1}$ Antónia Silva², António Sarmento'
}

Bilateral facial palsy is a rare clinical entity, which is often a special finding of a systemic disease, occurring in $0.3 \%$ to $2.0 \%$ of facial palsy cases ${ }^{1,2}$. Many of them are potentially life-threatening, and therefore the condition requires urgent medical intervention. Bacterial meningitis, Lyme Disease, (Bannwarth syndrome), syphilis, infectious mononucleosis, Guillan Barré syndrome, leukemia, sarcoidosis, Mobius syndrome are the most common cause of bilateral facial paralysis ${ }^{3,4}$.

In this paper, we present a case of a previously healthy in young woman, who was hospitalized with symptoms of meningitis associated with herpetic infection.

\section{CASE}

A 16-year-old female without history of previous medication or illness presented to her primary care physician with a 1-day history of severe headache. One day later she presented with fever, nausea, vomiting, photophobia, meningeal signs and petichial skin bruising.

She was hospitalized due to probable meningococcal meningitis.

Past medical history - No medical or significant history. Vaccination schedule in order (as recommended by the National Plan of Vaccination).

Medication - No medication habits.

Allergies to medication - Not of her knowledge.

Family history - No relevant family medical history.

Social history - Student, no recent contact with ill colleagues, no contact with animals, no recent travels, does not smoke/ drink and takes no illicit drugs.

Physical examination - During examination, the patient was awake, alert and aware, her temperature was $36.7^{\circ} \mathrm{C} / 98.06^{\circ} \mathrm{F}$, pulse: $100 / \mathrm{min}$, respiratory rate $18 / \mathrm{min}, \mathrm{SatO}_{2}: 100 \%\left(\mathrm{FiO}_{2}\right.$ : $21 \%$ ) and blood pressure: $113 / 79 \mathrm{mmHg}$. The eyes, ears, nose and throat were all normal. There was no parotid gland enlargement or adenomegaly. Heart and lung auscultation were normal. The abdomen was soft and nontender, without organomegaly, bowel sounds were normal. The relevant basic laboratoy valves are shown in Table 1.

Began empirical antibiotherapy with ceftriaxone $2 \mathrm{gr} \mathrm{BID/}$ IV and corticotherapy (dexamethasone). On the third day of her admission to the hospital the patient developed vesicular skin lesions on the left side of her face suggesting herpes and was treated with acyclovir topical five times a day.

From the previous CSF study no agent was isolated, except for Neisseria meningitidis. C-Reactive Protein DNA from Herpes simplex virus 1 and 2 (HSV1/2), Cytomegalovirus (CMV), EpsteinBarr (EBV), Varicella zoster virus (VZV), Mycoplasma pneumoniae (MP) and Mycobacterium tuberculosis were negative. The screening for RNA Enterovirus was also negative. The research for Borrelia burgdorferi, Wright reaction, Veneral Disease Research Laboratory test, Treponema pallidum hemagglutination, as well as for the direct and cultural mycobacteriological exam were negative. Table 2 shows the study results.

Antibodies to hepatitis virus $\mathrm{C}$, HBs atg and the Human Immunodeficiency Virus (HIV) were negative. And so were ANA and ANCA.

Table 1. Relevant basic laboratory values.

\begin{tabular}{ll}
\hline Serum & Results \\
\hline White blood cell count & $31.43 \times 10^{3} / \mathrm{uL}$ \\
(WBC)/Neutrophils & $(91.9 \%)$ \\
C-Reactive Protein (CRP) & $94.6 \mathrm{mg} / \mathrm{L}$ \\
Cerebrospinal fluid (CSF) & \\
WBC count/lymphocytes & $17.540 / \mathrm{uL}$ \\
Proteins & $0.80 \mathrm{~g} / \mathrm{L}$ \\
Glucose* & $0.15 \mathrm{~g} / \mathrm{L} /(0.80 \mathrm{~g} / \mathrm{L})$ \\
Gram stain & gram negative cocci \\
\hline
\end{tabular}

*serum glucose.

\section{PARALISIA FACIAL BILATERAL EM JOVEM APÓS MENINGITE MENINGOCÓCICA ASSOCIADA A INFECÇÃO HERPÉTICA}

'Department of Infectious Diseases, Medical School, University of Porto, Portugal; ${ }^{2}$ Department of Neurology, Medical School, University of Porto, Portugal.

Received 28 November 2008, received in final form 20 May 2009. Accepted 15 June 2009.

Dra. Edna Quintas - Serviço de Doenças Infecciosas / Hospital de São João - Al. Prof. Hernâni Monteiro - 4200-319 Porto - Portugal. E-mail: edna19d@ hotmail.com 
Table 2. Serological study.

\begin{tabular}{ccccccccccc}
\hline \multirow{3}{*}{ Serum } & VDRL $/$ & & & HSV1 & HSV2 & EBV & CMV & MP & \\
& TPHA & VZV & Wright & IgM/IgG & IgG/IgM & IgG/IgM & IgG/IgM & IgG/IgM & Lyme \\
\hline & $-/-$ & - & - & $189 /+$ & $-/-$ & $+/-$ & $+/-$ & $-/-$ & - \\
\hline
\end{tabular}

Table 3. Evolution of the CSF analysis.

\begin{tabular}{lccc}
\hline Cerebrospinal fluid (CSF) & Initial study & After 7 days of treatment & Neurology service (after 21 days) \\
\hline WBC count/lymphocytes & $17.540 / \mathrm{uL}$ & $260 / \mathrm{uL}$ & $59 / \mathrm{uL}$ \\
Proteins & $0.80 \mathrm{~g} / \mathrm{L}$ & $1.07 \mathrm{~g} / \mathrm{L}$ & $0.77 \mathrm{~g} / \mathrm{L}$ \\
Glucose & $0.15 \mathrm{~g} / \mathrm{L}$ & $0.46 \mathrm{~g} / \mathrm{L}$ & $0.43 \mathrm{~g} / \mathrm{L}$ \\
\hline
\end{tabular}

Table 4. Serologic study.

\begin{tabular}{|c|c|c|c|c|c|c|c|c|c|}
\hline Serum & $\begin{array}{c}\text { VDRL / } \\
\text { TPHA }\end{array}$ & VZV & Wright & $\begin{array}{c}\text { HSV1 } \\
\lg M / \lg G\end{array}$ & $\begin{array}{c}\mathrm{HSV} 2 \\
\lg / \operatorname{Ig} M\end{array}$ & $\begin{array}{c}\text { EBV } \\
\operatorname{lgG} / \lg M\end{array}$ & $\begin{array}{c}\text { CMV } \\
\text { IgG/IgM }\end{array}$ & $\begin{array}{c}M P \\
\lg G / \lg M\end{array}$ & Lyme \\
\hline $1^{\text {st }}$ study & $-1-$ & - & - & $189 /+$ & $-/-$ & $+/-$ & $+/-$ & $-1-$ & - \\
\hline $2^{\text {nd }}$ study & $-/-$ & - & - & $188.9 /+$ & $-1-$ & $+/-$ & $+/-$ & $-1-$ & - \\
\hline
\end{tabular}

After 7 days of therapy with ceftriaxone, she still complained of headache, did brain and ear computed tomography scan, that showed no abnormalities and repeated lumbar puncture.

The CSF analysis revealed white blood cell WBC 260/uL, a persisting high protein level of $1.07 \mathrm{~g} / \mathrm{L}$, glucose of $0.46 \mathrm{~g} / \mathrm{L}$.

A cervical echography and chest $\mathrm{X}$-rays showed no abnormalities.

Ceftriaxone was changed to ampicillin for more 5 days. On the eleventh day of admission, the patient complained of difficulty in articulating some words, but showed no other signs and symptoms. The neurological examination was normal. After clinical recovery, she was discharged after 13 days of hospitalization.

One week later, she returned to the hospital with difficulty in opening her mouth and articulating words. She was examined by a neurologist and was admitted in the Neurological Department.

\section{Neurological examination}

Mental status - Alerted, oriented. Speech: difficulty in articulating words.

Cranial nerves - No alteration in visual acuity. Isocoric, photoreactive pupils. No ophthalmoparesis.

Normal facial sensibility. Bilaterally diminished nasogenian furrows, mainly on the left side of the face. No face mimics.

All other cranial pairs normal.

The motor and sensitive examination of trunk and extremities was normal. She had no nuchal rigidity or other meningeal signs.

Repeated lumbar puncture and the CSF exam revealed: WBC 59/uL, glucose of $0.43 \mathrm{~g} / \mathrm{L}$, protein of $0.77 \mathrm{~g} / \mathrm{L}$, as shown in Table 3 .

All analysis made in the previous admission were repeated showing no abnormalities. PCR for Herpes virus in the CSF was negative, though with positive serologies for HSV1 (Table 4).

Electromyography showed severe signs of axonal lesion of both facial nerves. The brain MRI (magnetic resonance imaging) showed abnormal bilateral Gadolinium enhancement in the intracanalicular part of both facial nerves, and there was no evidence of any parenchymal lesions (Fig 1).

The diagnosis of bilateral peripheral facial palsy, probably associated to an infection with Herpes simplex virus was made and treated with acyclovir $800 \mathrm{mg}$ five times a day Per Os, during 7 days. Support measures were also taken, namely physiotherapy, artificial tear eye drops several times a day and occlusive eye dressing on both eyes during the night. She improved on this regimen with completely resolution of her facial palsies, some weeks later.

\section{DISCUSSION}

The causes of peripheral facial paralysis includes many conditions such as congenital, traumatic, infectious, neu-
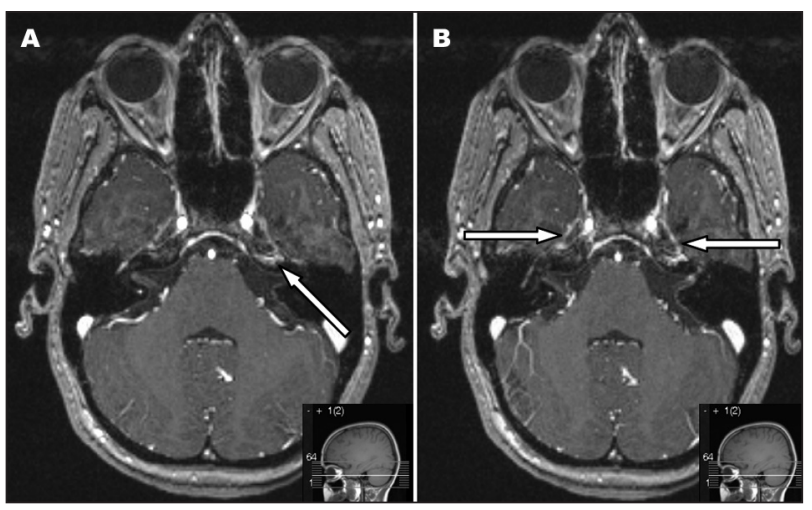

Fig 1. T7-weighted coronal sections through the internal auditory canal. [A] Precontrast view and [B] postcontrast view after gadolium administration. Note the enhancement of intracanalicular part of both facial nerves (arrows). 
rological/neuromuscular disorders, metabolic, neoplastic, toxic, vascular, autoimmune, iatrogenic and idiopathic ${ }^{3,5}$.

The etiology of Bell's palsy is not completely understood $^{6-9}$. Unlike unilateral facial paralysis, where the cause is mostly idiopathic (over $50 \%$ ), bilateral facial palsy is less often idiopathic (under $20 \%$ ). Various infectious agents have been linked to facial palsy, such as the Herpes simplex and Varicella zoster viruses, mumps and the rubella virus, cytomegalovirus and HIV as well as Borrelia burgdorferi, ${ }^{1,6}$. Mycoplasma pneumoniae is the other important pathogen of upper and lower respiratory tract infections, which may cause extrapulmonary complications, namely in the central nervous system - meningoencephalitis and occasionally peripheral facial palsy ${ }^{10-12}$.

More recently, the Herpes simplex virus has been implicated in the pathogenesis of Bell's palsy ${ }^{13}$. Neisseria meningitis is a gram-negative diplococcus that can also cause peripheral facial palsy. It is still a cause of endemic and epidemic disease in developed ${ }^{14,15}$ and developing nations ${ }^{16,17}$. This infection is a worldwide major public health problem. Children account for the vast majority of these cases.

A thorough history, a complete physical examination, and an exhaustive laboratory search are needed to clarify the etiology of bilateral facial paralysis. The entire process should include a complete blood cell count, blood biochemistry, C-reactive Protein, cerebrospinal fluid examination, immunoassay for EBV, CMV, HSV, Lyme disease and the Syphilis test. A complete microbiologic study and radiologic examination (computed tomography and/or magnetic resonance imaging) of temporal bone, brain and chest should also be done. Effectively, all the above-mentioned exams to establish the diagnosis.

In the present case, it was identified the etiologic agent - Neisseria meningitides, confirmed by the culture exam in the CSF. Gadolium enhancement was noticed in the intracanalicular part of both facial nerves. This finding advocated with neurological examination and electromyography supports the diagnosis of bilateral peripheral facial palsy after infection with bacterial meningitis. Antibiotherapy and corticotherapy were administered in the first four days of hospitalization.

In the second phase, when she was readmitted to the hospital, herpes simplex virus infection was diagnosed and she was medicated with acyclovir. She improved over the next days, and was discharged.

Although it was not identified by PCR of the HSV-1 in the CSF, there persisted positive serologies for herpes. If we consider the time when meningitis and the facial herpes appeared we tend to believe that it may be associated with the patient's clinical condition.

In summary, this is a report of a young woman with meningococcal meningitis complicated by bilateral peripheral facial palsy. Bilateral palsies usually reflect an underlying systemic pathology, and the prognosis is dependent on the etiology.

If the etiology can be identified and successfully dealt with the prognosis is excellent, but may be worse in elderly people, especially in immunocompromised individuals.

Patients with bilateral facial palsies need thorough assessment and follow-up.

\section{REFERENCES}

1. Roberg M, Ecrudh J, Forsberg P. Acute peripheral facial palsy: CSF findings and etiology. Acta Neurol Scand 1991;83:55-60.

2. Stahl WFT. Recurrent bilateral peripheral facial palsy. J Laryngol Otol 1989;103:117-119.

3. Price T, Fife DG. Bilateral simultaneous facial nerve palsy. J Laryngol Otol 2002;116:46-48.

4. Kilic R, Ozdek A, Felek S, Safak MA, Samin E. A case presentation of bilateral simultaneous Bell's palsy. Am J Otolaryngol 2003;24:271-273.

5. Gevers GLP. Bilateral simultaneous facial paralysis-differential diagnosis and treatment options. A case report and review of literature. Acta Otorhinolaryngol Belg 2003;57:139-146.

6. Morgan M, Nathwani D. Facial palsy and infection: the unfolding story. Clin Infect Dis 1992;14:263-271.

7. Abele-Horn M, Franck W, Busch U, Nitschko H, Roos R, Hecsemann J. Transverse mielitis associated with Mycoplasma pneumoniae. Clin Infect Dis 1998;26:909-912.

8. Shaitkin BM, May M, Podrinec M, Ulrich J, Peitersen E, Klein SR. Idiopathic (Bell's) palsy, herpes zoster cephalicus, and other facial nerve disorders of viral origin: In: May M, Shaitkin BM (Eds). The facial nerve, May's. $2^{\text {nd }}$ Ed. New York: Thieme Medical Publishers, 2000:319.

9. Mandell GL, Bennett JE, Dolin R. Principles and practice of infectious diseases. $6^{\text {th }}$ Edition, 2005.

10. Fink CG, Butler L. A cranial nerve palsy associated with Mycoplasma pneumoniae infection. Br J Ophthalmol 1993;77:750-751.

11. Klar A, Gross-Klieselstein E, Hurvitz H, Branski D. Bilateral Bell's palsy due to Mycoplasma pneumoniae infection. ISR J Med SCI 1985;21:692-694.

12. Wang $\mathrm{C}-\mathrm{H}$, Chou $\mathrm{M}-\mathrm{L}$, Huang $\mathrm{C}-\mathrm{H}$. Benign Isolated abducens nerve palsy in Mycoplasma pneumoniae infection. Pediatr Neurol 1998;18:71-72.

13. Schirm J, Mulkens PSJZ. Bell's palsy and herpes simplex virus. APMIS 1997;105:815-823.

14. Patel MS, Meriands A, Hanna JN, et al. Epidemic meningococcal meningitis in central Australia. Med J Aust 1993;158:336-340.

15. Durand ML, Calderwood SB, Weber DJ, et al. Acute bacterial meningitis in adults. A review of 493 episodes. N Engl J Med 1993;328:21-28.

16. Girgis NI, Sippel JE, Kilpatrick WR, et al. Meningitis and encephalitis at the Abbassia Fever Hospital Cairo, Egypt from 1966 to 1989. Am J Trop Med Hyg 1993;48:97-107.

17. Nejmi S, Belhaj A, Guibourdenche M, et al. Study of ninety strains of serogroup A Neisseria meningitidis isolated from cerebroespinal fluid (25) and rhinopharynx (65) in Marocco (December 1989-April 1990). Pathol Biol (Paris) 1992;40:993-998. 